(C) 1989 ISIJ

////////////////////

論 文

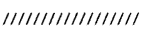

溶融 $\mathrm{Ni}$ および $\mathrm{Ni}-\mathrm{Fe}$ 合金の珪素 による脱酸平衡

\author{
石 井 不二夫**萬 谷 志 郎*
}

\title{
Deoxidation of Liquid Nickel and Nickel-Iron Alloy with Silicon
}

Fujio ISHII and Shiro BAN-YA

\section{Synopsis :}

The deoxidation of liquid nickle with silicon was studied at the temperature ranging from $1500^{\circ} \mathrm{C}$ to $1650{ }^{\circ} \mathrm{C}$ using silica crucible in order to investigate the deoxidation of nickel based alloys.

The effect of temperature on the equilibrium constant of the deoxidation reaction was found to be : $\log K_{\mathrm{Si}(\mathrm{Ni})}=-15680 / T+1.83 \quad 1500 \sim 1650^{\circ} \mathrm{C}$

while the deoxidation product of nickle, $\log K_{\mathrm{Si}(\mathrm{Ni})}^{\prime}\left(=[\% \mathrm{Si}][\% \mathrm{O}]^{2}\right)$, was expressed as follows : $\log K_{\mathrm{Si}(\mathrm{Ni})}^{\prime}=\log K_{\mathrm{Si}(\mathrm{Ni})}-0.06[\% \mathrm{Si}] \mathrm{Si}<2 \%, 1500 \sim 1650^{\circ} \mathrm{C}$

The deoxidation of nickle-iron binary with silicon was measured over the all range of the binary system including pure iron at temperatures of $1600^{\circ} \mathrm{C}$ and $1650^{\circ} \mathrm{C}$. On the nickle basis, the deoxidation product of nickle-iron alloy, $\log K_{\mathrm{Si}(\mathrm{Ni}-\mathrm{Fe})}^{\prime}$, which increased by the addition of iron, was empirically represented to be : $\log K_{\mathrm{Si}(\mathrm{Ni}-\mathrm{Fe})}^{\prime}=\log K_{\mathrm{Si}(\mathrm{Ni})}-(288 / \mathrm{T}-0.197)[\% \mathrm{Fe}] \quad \mathrm{Fe}<20 \%, 0.5 \% \mathrm{Si}, 1600 \sim 1650^{\circ} \mathrm{C}$

The temperature dependence of the equilibrium constant for the deoxidation of iron, $\log K_{\mathrm{Si}(\mathrm{Fe})}$, was given by the expression :

$$
\log K_{\mathrm{Si}(\mathrm{Fe})}=-30960 / T+11.86 \quad 1550 \sim 1650^{\circ} \mathrm{C}
$$

On the iron basis, the value of $\log K_{\mathrm{Si}(\mathrm{Fe}-\mathrm{Ni})}^{\prime}$, which decreased with increasing nickle content, was calculated as :

$$
\log K_{\mathrm{Si}(\mathrm{Fe}-\mathrm{Ni})}^{\prime}=\log K_{\mathrm{Si}(\mathrm{Fe})}-0.01[\% \mathrm{Ni}] \quad \mathrm{Ni}<60 \%, 0.5 \% \mathrm{Si}, 1600 \sim 1650^{\circ} \mathrm{C}
$$

Key words : deoxidation; $\mathrm{Si} ; \mathrm{Ni} ; \mathrm{Ni}-\mathrm{Fe}$ alloy ; equilibrium constant ; deoxidation product.

\section{1. 緒言}

$\mathrm{Ni}$ 基合金はパーマロイのように, 電子・磁性材料とし て従来より使用されているが, 近年, 電子産業が高い成 長を続けるなかで, 電子部品の主要材料としてその需要 が急増している，他方，同合金は酎熱・酎食材料として 優れた特性を示し, 核反応器および熱交換器の材料やガ スタービンのディスクやブレード等の材料に用いられて いる. $\mathrm{Ni}$ 基合金はこのように，その用途が多岐にわたり， それぞれの特性を生かして使用されており, 現在でも新 たな用途のために合金の開発が進められている。した がって，合金に関する研究は主に耐熱性および高温酎酸 化性に関連したものが多い. しかしながら， Ni 合金の 製造ではことに $\mathrm{Ni}$ 基合金のスクラップの再利用を考 慮すると, $\mathrm{C}, \mathrm{O}, \mathrm{N}, \mathrm{S}$ など微量不純物元素の除去な らびに制御が重要であるが， $\mathrm{Ni}$ 系合金に関する基礎的 な研究は少なく, 熱力学的資料は不足している.

著者らは先に $\mathrm{Ni}$ 合金の窒素溶解度について報告 ${ }^{1)} し$
たが, 本研究は溶融 $\mathrm{Ni}$ 合金の脱酸に関する研究として まず珪素をとりあげ, $\mathrm{SiO}_{2}$ 飽和における $\mathrm{Ni}$ 中の珪素一 酸素の平衡関係を明らかにすることを目的として, $1500^{\circ} \mathrm{C}, 1550^{\circ} \mathrm{C}, 1600^{\circ} \mathrm{C}$ および $1650^{\circ} \mathrm{C}$ の各温度で 脱酸平衡を測定した。さらに，その結果を基に $\mathrm{Ni}-\mathrm{Fe}$ 2 元系全域にわたり珪素による脱酸平衡を測定した.

\section{2. 実 験 方 法}

実験装置は前報 ${ }^{23)}$ に使用したものと同一であり，そ の概略を述べる。

\section{$2 \cdot 1$ 実験装置}

装置は $\mathrm{Ar}$ と $\mathrm{H}_{2}$ のガス精製装置, 流量計および反心 管よりなっている. 反応管は外径 $67 \mathrm{~mm}$, 内径 $56 \mathrm{~mm}$, 長さ $500 \mathrm{~mm}$ の不透明石英管で, 溶解試料を入れた $\mathrm{SiO}_{2}$ るつぼをさらに $\mathrm{SiO}_{2}$ 製保護るつぼに入れて反応 管内に設置する。試料溶解には $10 \mathrm{kVA}$ 真空管式高周波 誘導炉を使用し，温度測定には，水素気流中で溶解した 溶鉄と溶融 $\mathrm{Ni}$ の融点で補正した光高温計を用いた. 


\section{$2 \cdot 2$ 溶解試料および使用材料}

溶解試料として Ni および鉄には電解ニッケルと電解 鉄を用い, 脱酸元素としては $99.99 \%$ の珪素を使用した。

実験に用いたるつぼは不透明石英管より作製した $\mathrm{SiO}_{2}$ るつほ（内径 $25 \mathrm{~mm}$, 外径 $32 \mathrm{~mm}$, 高さ $50 \mathrm{~mm}$ ) および $\mathrm{SiO}_{2}$ 保護るつぼであり，るつほ間には $\mathrm{SiO}_{2}$ 粒 を充填した。また，Arと $\mathrm{H}_{2}$ は市販のボンベガスで， それぞれ精製装置を通して精製し，100～120 ml/min 使 用した。

\section{$2 \cdot 3$ 試料の化学分析}

採取した試料中の酸素走量にはアルゴン送気電量測定 装置を用いた，酸素の定量值は数 ppm から 100 ppm の 範囲であったが, 酸素濃度が $10 \mathrm{ppm}$ 以下では定量值の 再現性はほほ土 $1 \mathrm{ppm}$, 酸素濃度 $100 \mathrm{ppm}$ 程度では土 $5 \mathrm{ppm}$ 以内であった. 珪素の定量には ICP 発光分光分 析装置（ICAP-500，SPC-1200）を用いたが，珪素の 定量限界は 0.001 mass\%であった。また， Ni- $\mathrm{Fe}$ 合金 では，Niをジメチルグリオキシム重量法により定量し て鉄濃度を算出した。

\section{$2 \cdot 4$ 実験操作}

電解ニッケル (約 $22 \mathrm{ppm} \mathrm{O}$ ) 約 $120 \mathrm{~g}$ と少量の $\mathrm{NiO}$ を人れたるつぼを友応管内に設置し，Ar を導入して溶 解する. 珪素濃度が 0.7 mass\% 以上の測定では電解二ッ ケルのみを使用し，必要に忍じて $\mathrm{Ar}-\mathrm{H}_{2}$ 混合ガス気流 中で溶解した。また $\mathrm{Ni}-\mathrm{Fe}$ 令金系では， $\mathrm{Ni}$ と鉄を配合 して 1 回に約 $100 \mathrm{~g}$ を用いたが, 電解鉄中の酸素濃度が 高いため, $\mathrm{Ar}-\mathrm{H}_{2}$ 混介ガス気流中に保持して溶解酸素 を減じた。 その後, $\mathrm{Ar}$ 気流中で所定の温度に保持して から, 内径約 $3 \mathrm{~mm}$ の不透明石英管で脱酸剤添加前にお ける酸素分析試料を採取する，その後，直ちに珪素を添 加し，所定の時間ごとに溶融試料約 $10 \mathrm{~g}$ を吸引採取し て，水中で急冷した．Fig. 1 に溶融 $\mathrm{Ni}$ の珪素脱酸にお ける酸素濃度の経時变化の数例を示す．珪素を添加する

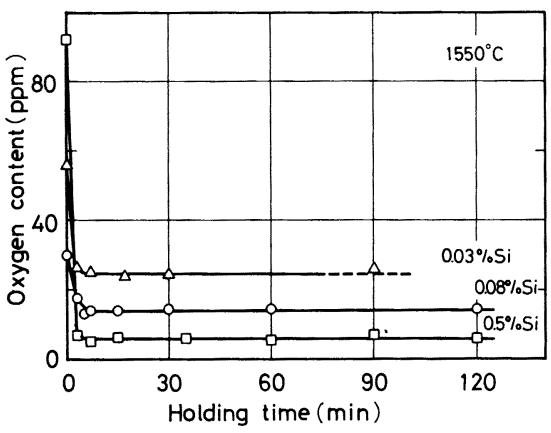

Fig. 1. Deoxidation curves of liquid nickel with silicon.
と, 酸素濃度は急激に減少し，15 min 以後はほぼ一䇥 值を示している。 Ni-Fe 合金系では珪素約 0.5 mass\% を添加したが，平衡に達する時間は $\mathrm{Ni}$ の場合と同様で あった。これらの結果より, 平衡時間は $15 \mathrm{~min}$ で十分 であるが，安全のために，30，60，90 min 保持した後 にそれぞれ試料採取を行い，さらに温度を変えて，所定 の温度に保持してから，再び $30 ， 60,90 \mathrm{~min}$ 後に試料 を採取した。

本研究では $\mathrm{SiO}_{2}$ るつぼを使用している関係上，溶融 $\mathrm{Ni}$ では $1500^{\circ} \mathrm{C} \sim 1650^{\circ} \mathrm{C}$ の範井で, $\mathrm{Ni}-\mathrm{Fe}$ 系では

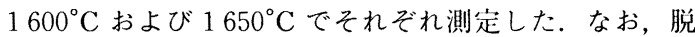
酸生成物は $\mathrm{SiO}_{2}$ であることをX線ディフラクトメー ターにより確認した。

\section{3. 実験結果および考察}

\section{$3 \cdot 1$ ニッケル-珪素-酸素系}

$3 \cdot 1 \cdot 1$ 溶融 $\mathrm{Ni}$ の珪素脱酸平衡

珪素による溶融 $\mathrm{Ni}$ の脱酸反応式は(1)式で示され, その平衡定数は( 2 )式で表される.

$$
\begin{aligned}
& \mathrm{SiO}_{2}(\mathrm{~s})=\underline{\mathrm{Si}}+2 \underline{\mathrm{O}} \\
& K_{\mathrm{SiN \textrm {i }} /}=a_{\mathrm{Si}} \cdot a_{0}^{2} / a_{\mathrm{SiO}_{2}}
\end{aligned}
$$

ここで活量 $a_{\mathrm{si}} ， a_{0}$ は珪素と酸素の濃度を mass\%でそ れぞれ表し，活量の基準を無限希薄溶液にとり，活量 $a_{\mathrm{SiO}_{2}}$ は固体 $\mathrm{SiO}_{2}$ に基準をとる. $a_{\mathrm{SiO}_{2}} \fallingdotseq 1$ とすれば, ( 2 )式は( 3 )式となり，珪素による脱酸の濃度積は(4) 式で表される。

$$
\begin{aligned}
& K_{\mathrm{Si}(\mathrm{Ni})}=a_{\mathrm{Si}} \cdot a_{0}^{2}=f_{\mathrm{Si}}[\% \mathrm{Si}] \cdot f_{0}^{2}[\% \mathrm{O}]^{2} \\
& K_{\mathrm{Si}(\mathrm{Ni})}^{\prime}=[\% \mathrm{Si}] \cdot[\% \mathrm{O}]^{2} \ldots \ldots \ldots \ldots \ldots \ldots \ldots \ldots \ldots \ldots \ldots \ldots \ldots \ldots
\end{aligned}
$$

( 3 )および ( 4 )式を対数にとり，組み合わせて整理する と, $\log K_{\mathrm{SiNi} i)}^{\prime}$ は ( 5 )式で示される.

$$
\begin{aligned}
\log K_{\mathrm{Si}(\mathrm{Ni})}^{\prime} & =\log K_{\mathrm{Si}(\mathrm{Ni})}-\log f_{\mathrm{Si}}-2 \log f_{0} \\
& =\log K_{\mathrm{Si}(\mathrm{Ni})}-\left(\log f_{\mathrm{Si}}^{\mathrm{si}}+\log f_{\mathrm{Si}}^{\mathrm{o}}\right) \\
& -2\left(\log f_{0}^{0}+\log f_{0}^{\mathrm{Si}}\right) \\
& =\log K_{\mathrm{Si}(\mathrm{Ni})}-\left(e_{\mathrm{Si}}^{\mathrm{Si}}+2 e_{0}^{\mathrm{Si}}\right)[\% \mathrm{Si}] \\
& -\left(e_{\mathrm{Si}}^{0}+2 e_{0}^{0}\right)[\% \mathrm{O}] \\
& \fallingdotseq \log K_{\mathrm{Si}(\mathrm{Ni})}-\left(e_{\mathrm{Si}}^{\mathrm{Si}}+2 e_{0}^{\mathrm{Si}}\right)[\% \mathrm{Si}] \cdots(5)
\end{aligned}
$$

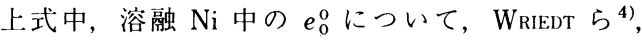

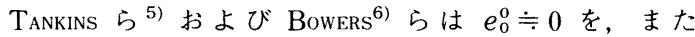
$\mathrm{EMF}$ 法を用いた $\mathrm{JACOB}^{7)}$ は $\log f_{\mathrm{o}}^{0}=-0.0374$ [at \% O ] を報告している。 また本研究に打ける測定範囲では酸素 含有量は最大 $[\% \mathrm{O}]<0.01$ であったので，測定䛊差の 範囲内で $\left(e_{\mathrm{Si}}^{0}+2 e_{0}^{0}\right)[\% \mathrm{O}] \fallingdotseq 0$ とすることができ, $\log K_{\mathrm{SiNi}}^{\prime}$ は( 5$)$ 式のように近似的に $[\% \mathrm{Si}]$ の関数とし て示される.

珪素濃度 0.001 から 2 mass\%, $1500^{\circ} \mathrm{C}$ から $1650^{\circ} \mathrm{C}$ 
における測定結果より脱酸の濃度積 $\log K_{\mathrm{Si} \text { (i) }}^{\prime}$ を求め, 珪素濃度との関係を Fig. 2 に示寸。 $\log K_{\mathrm{SiNi}}^{\prime}$ は各温度 において 2 mass\%までわずかに減少する傾们がある. 酸素濃度が十分低く, 分析の難しさにもとづく測定值の ばらつきがあるので, 各淔線の勾配に温度依保性が認め られないものとすれば, 各泊線は(6)式で表され, 各温 度における標準偏着は $\sigma= \pm 0.084$ 以下であった。

$\log K_{\mathrm{SiN \textrm {Ni }}}^{\prime}=\log K_{\mathrm{SiNi}}-0.06[\% \mathrm{Si}]$

$\mathrm{Si}<2$ mass $\%$

また，各温度における $\log K_{\mathrm{SiNi}}$ として Table 1 に示す 值を得た。これらの值より $\log K_{\mathrm{Si} \text { i i }}$ の温度式は( 7 )式 となり, 従来報告された値と比較して Fig. 3 に示す.

$\log K_{\mathrm{SiN \textrm {Ni }}}=-15680 / T+1.83$

OELSFN と KREMER $^{8)}$ の值は実測值より著者らが算山し たものであり， TARAKANOV ら ${ }^{9) 10)}$ の值は网面より読み 取った值である. 他方, SchweridtFeger と Engill. ${ }^{11)}$ は, 彼ら自身の实測值である $\gamma_{\mathrm{Si}}^{\circ}=0.0001$ および純 $\mathrm{Si}(\mathrm{l})$ と $\mathrm{O}_{2}(\mathrm{~g})$ から $\mathrm{SiO}_{2}(\mathrm{~s})$ を生成する文忍の $\Delta G^{\circ}$ と, 溶 融 $\mathrm{Ni}$ への酸素溶解㪀心に関する BowERSによる(9)式 の $\Delta G^{\circ 6)}$ を組み命わせて得た值 $\log K_{\mathrm{SiN \textrm {i }}}=-6.24$ を 提出している. また, 藤原と杉浦 ${ }^{12)}$ は同様に, $\gamma_{\mathrm{Si}}^{\circ}=$ 0.01 と文献值を組み今わせた検徑值を報告している.

㲸中, SigWORTH ら ${ }^{13)}$ の㨁線は TARAKANOV らの值をも とにして予測されたものと思われる. Fig. 3 で明らかな

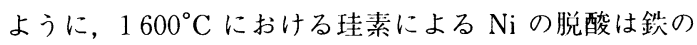
場合より約 100 倍大きい。これら $\log K_{\mathrm{Si}|\mathrm{Ni}|}$ の值をまと めて Table 2 に示す.

\section{$3 \cdot 1 \cdot 2$ 相互作用係数の検䣓}

$\mathrm{Ni}-\mathrm{Si}-\mathrm{O}$ 系において Henry 則が成り立つならば( 3 ) 式の活量係数は $f_{\mathrm{Si}}=1, f_{0}=1$ となり, $\log K_{\mathrm{Si} \mathrm{Ni}}=$ $\log K_{\mathrm{SiNi}}^{\prime}$ となる. しかし, Fig. 2 および( 6 代で表さ れるように $\log K_{\text {SiNi }}^{\prime}$ は珪素濃度とともにわずかに減少

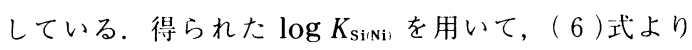
$\mathrm{Ni}$ 中の珪素と酸素の濃度を算出して対数関係で示すと

Table 1. Observed values of $\log K_{\mathrm{Si}(\mathrm{Ni})}$.

\begin{tabular}{lrrrr}
\hline$T\left({ }^{\circ} \mathrm{C}\right)$ & 1650 & 1600 & 1550 & 1500 \\
$\log K_{\mathrm{Si}(\mathrm{Ni})}$ & -6.32 & -6.54 & -6.77 & -7.01 \\
\hline
\end{tabular}

Fig. 4 の直線群となる. 0.5 mass\% までは珪素と酸素の 関係は $-1 / 2$ の杓配の直線でホされるが, さらに珪素 濃度が高くなると、この陗線より幾分負に偏倚している. 汹中の OELSEN と KREMER ${ }^{8)}$ および TARAKANOV ら ${ }^{9110)} の$ 結果は本研究結果とほぼ同じ傾们を示している.

実測值から得られた $(6)$ 式と（5) 式の関係より $e_{\mathrm{si}}^{\mathrm{Si}}+$ $2 e_{0}^{\mathrm{Si}}=0.06$ が得られ，したがって，一方の相五作用係 数が走まれば他方を知ることができる。しかしながら， 従来の $e_{\mathrm{si}}^{\mathrm{Si}}$ および $e_{0}^{\mathrm{Si}}$ に関する研究は十分ではなく, TARAKANOV ら ${ }^{9) 10)} の e_{\mathrm{Si}}^{\mathrm{Si}}=0.19$ および\}想值として SIGWORTH ら ${ }^{13)}$ の $e_{\mathrm{Si}}^{\mathrm{si}}=0.11$ があるのみである. 実測值か

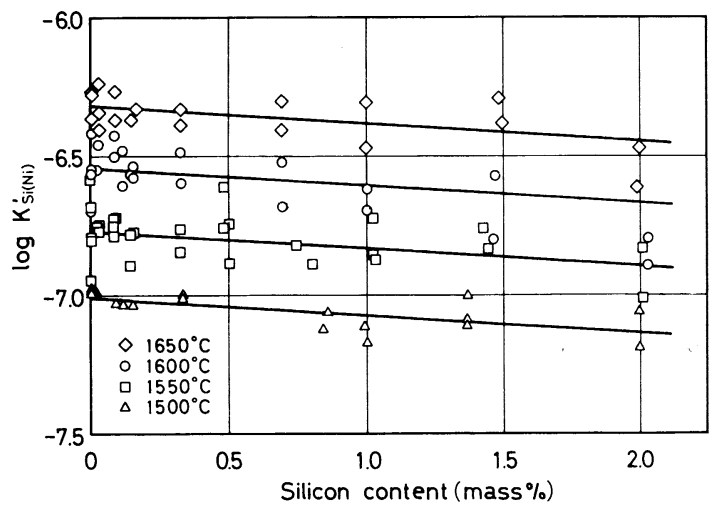

Fig. 2. Plot of $\log K_{\mathrm{Si}(\mathrm{Ni})}^{\prime}$ vs. silicon content.

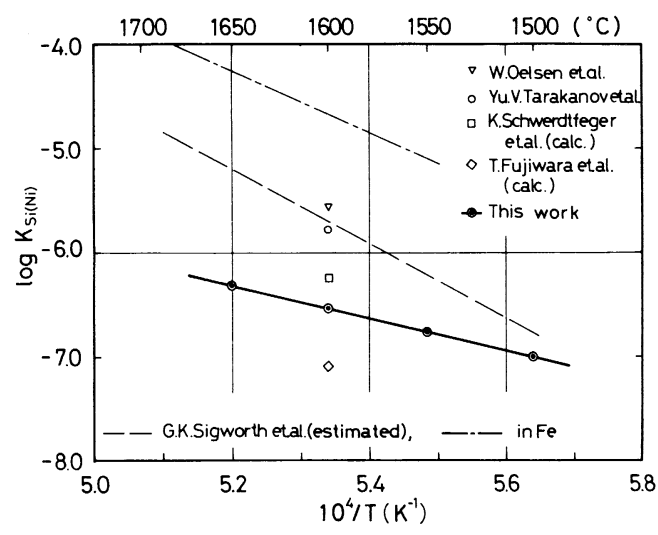

Fig. 3. Temperature dependence of $\log K_{\mathrm{Si}(\mathrm{Ni})}$.

Table 2. $\log K$ of the reaction, $\mathrm{SiO}_{2}(\mathrm{~s})=\underline{\mathrm{Si}}+2 \underline{\mathrm{O}}$, in liquid nickel at $1600^{\circ} \mathrm{C}$.

\begin{tabular}{|c|c|c|c|}
\hline Author & Year & $\log K_{\mathrm{Si}(\mathrm{Ni})}$ & Remarks \\
\hline OELLSEN \& KREMER & 1936 & -5.54 & Calculated by the present authors \\
\hline TARAKANOV et al. & 1965 & -5.78 & \\
\hline SCHWERDTFEGER el al. & 1965 & -6.24 & Calculated from their $\gamma_{\mathrm{Si}}^{\circ}=0.0001$ and $\Delta G^{\circ}$ of $\mathrm{Si}(\mathrm{l})+1 / 2 \mathrm{O}_{2}(\mathrm{~g})=\mathrm{SiO}_{2}(\mathrm{~s})$ \\
\hline FujIWARA \& SUGIURA & 1977 & -7.09 & Calculated from $\gamma_{\mathrm{Si}}^{\circ}=0.01$ \\
\hline SIGWORTH el al. & 1977 & -5.79 & Estimated, $\log K_{\mathrm{Si}(\mathrm{Ni})}=-32940 / T+11.796$ \\
\hline This work & 1987 & -6.54 & $\log K_{\mathrm{Si}(\mathrm{Ni})}=-15680 / T+1.83$ \\
\hline
\end{tabular}




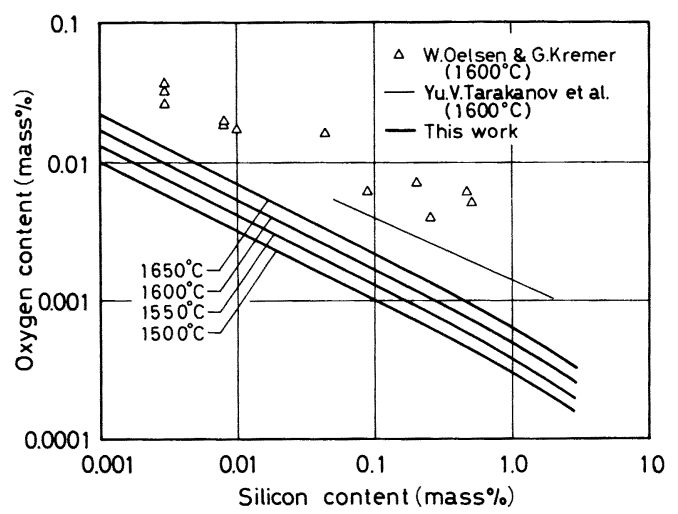

Fig. 4. Relation between $\mathrm{Si}$ and $\mathrm{O}$ in liquid nickel.

Table 3. Interaction parameter, $e_{0}^{\mathrm{Si}}$ in nickel at $1600^{\circ} \mathrm{C}$.

\begin{tabular}{lcc}
\hline \multicolumn{1}{c}{ Author } & $e_{0}^{\mathrm{Si}}$ & \multicolumn{1}{c}{ Remarks } \\
\hline TARAKANOV et al. & -0.137 & \\
JANKE \& FISCHER & & $\log f_{0}^{\mathrm{Si}}=-5.384[\% \mathrm{Si}]+9.318[\% \mathrm{Si}]^{2}$ \\
This work & -0.065 & $\begin{array}{l}\mathrm{Si} \\
\mathrm{Si}\end{array}=0.19 \quad[\% \mathrm{Si}]<2.0$ \\
\hline
\end{tabular}

Table 4. Comparison of $\gamma_{\mathrm{Si}}^{\circ}$ in nickel at $1600^{\circ} \mathrm{C}$.

\begin{tabular}{|c|c|c|}
\hline Author & $\gamma_{\mathrm{Si}}^{\circ}$ & Remarks \\
\hline TARAKANOV et al. & 0.00014 & \\
\hline SCHWERDTFEGER et al. & 0.0001 & \\
\hline FuJiWara \& SugluRa & 0.01 & $\Delta G^{\circ}(X)^{*}=-50000+17.6 T$ \\
\hline This work & 0.0001 & Calculated from $\log K_{\mathrm{Si}(\mathrm{Ni})}$ \\
\hline
\end{tabular}

$*(X)$ : Mole fraction

ら得られた TARAKANOV ら ${ }^{910)}$ の值を本研究結果に適用 すると, $e_{0}^{\mathrm{Si}}$ の予測值は -0.065 となりっこれらを

Table 3 に示す.

$3 \cdot 1 \cdot 3$ 純 $\mathrm{Ni}$ 中の $\gamma_{\mathrm{Si}}^{\circ}$ の予測

無限希薄溶液における珪素の $\gamma_{\mathrm{Si}}^{\circ}$ は次式より求めら れる。

$$
\begin{aligned}
& \mathrm{Si}(1)=\operatorname{Si}(\%) \\
& \Delta G^{\circ}=R T \ln \gamma_{\mathrm{si}}^{\circ} \cdot 0.5871 / 28.09
\end{aligned}
$$

(8)式は（1)，（9)，(10)の各式を組み命わせて導出さ れる.

$$
\begin{aligned}
& 1 / 2 \mathrm{O}_{2}(\mathrm{~g})=\underline{\mathrm{O}} \\
& \Delta G^{\circ}=-19055+1.71 T^{61}(\text { cal. }) \\
& \mathrm{Si}(\mathrm{l})+\mathrm{O}_{2}(\mathrm{~g})=\mathrm{SiO}_{2}(\mathrm{~s}) \\
& \Delta G^{\circ}=-227700+48.6 T^{14}(\text { cal. })
\end{aligned}
$$

(1)式の $\Delta G^{\circ}$ には本研究結果である( 7 )式を用いる. ( 9 ) 式の文忍に関する研究には $\mathrm{H}_{2} / \mathrm{H}_{2} \mathrm{O}, \mathrm{CO} / \mathrm{CO}_{2}$ お よび EMF 法による多数の報告4) 7)15) -21) があるので, これらの実測值を作汹して検討した結果, $\mathrm{CO} / \mathrm{CO}_{2}$ で 測定した Bowrrs ${ }^{6)}$ の䛧を採用した。また(10)式につい

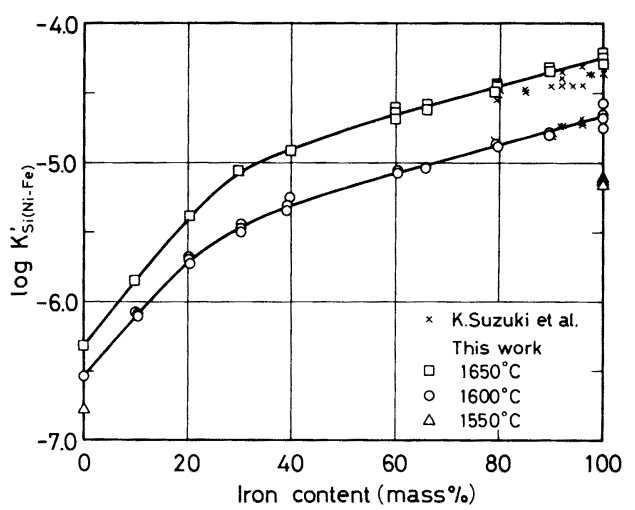

Fig. 5. Plot of $\log K_{\mathrm{Si}(\mathrm{Ni}-\mathrm{Fe})}^{\prime} v s$. iron content in $\mathrm{Ni}-\mathrm{Fe}$ alloys.

ては KUBASCHEWSKI ら ${ }^{14)}$ の値を使用した。

$\gamma_{\mathrm{Si}}^{\circ}$ の值は上述のように各式の $\Delta G^{\circ}$ である大きな数 值の組令せから導出されるため, 得られた值の精度は十 分でないと考えられるが，計算結果は次式となり， $1600^{\circ} \mathrm{C}$ の $\gamma_{\mathrm{Si}}^{\circ}$ を Table 4 に示す.

$$
\log \gamma_{\mathrm{Si}}^{\circ}=-25750 / T+9.7
$$

\section{$3 \cdot 2$ ニッケル-鉄-珪素-酸素系}

\section{$3 \cdot 2 \cdot 1$ ニッケル基今金としての脱酸平衡}

本系の平衡定数 $\log K_{\mathrm{SiNi}}$ は, 脱酸の濃度積 $\log$ $K_{\mathrm{SiNi}-\mathrm{Fe},}^{\prime}$, 活量係数および濃度を用いて整理すると (12) 式となる。

$$
\begin{aligned}
\log K_{\mathrm{Si}(\mathrm{Ni})} & =\log K_{\mathrm{Si}(\mathrm{Ni}-\mathrm{Fe}}^{\prime}+\log f_{\mathrm{Si}}^{\mathrm{Si}}+\log f_{\mathrm{Si}}^{0} \\
& +\log f_{\mathrm{Si}}^{\mathrm{Fe}}+2\left(\log f_{0}^{0}+\log f_{0}^{\mathrm{si}}+\log f_{0}^{\mathrm{Fe}}\right) \\
& =\log K_{\mathrm{Si}(\mathrm{Ni}-\mathrm{Fe}}^{\prime}+\left(e_{\mathrm{Si}}^{\mathrm{Si}}+2 e_{0}^{\mathrm{Si}}\right)[\% \mathrm{Si}] \\
& +\left(e_{\mathrm{Si}}^{o}+2 e_{0}^{\mathrm{o}}\right)[\% \mathrm{O}]+\left(e_{\mathrm{Si}}^{\mathrm{Fe}}+2 e_{0}^{\mathrm{Fe}}\right)[\% \mathrm{Fe}]
\end{aligned}
$$

右辽，第 2 項は前節で得られた值， $\left(e_{\mathrm{Si}}^{\mathrm{Si}}+2 e_{0}^{\mathrm{Si}}\right)=$ 0.06 を利用することができ, 珪素の添加量は約 0.5 mass\%である． $e_{0}^{\text {Si }}$ の值に先に求めた -0.065 を採用 すると, $e_{\mathrm{Si}}^{0} \fallingdotseq e_{0}^{\mathrm{Si}} \cdot \mathrm{M}_{\mathrm{Si}} / \mathrm{M}_{0}=-0.11$ となり, $e_{0}^{0} \fallingdotseq 0$ から $\left(e_{\mathrm{si}}^{0}+2 e_{0}^{0}\right)=-0.11$ が得られるが, $\mathrm{Ni}-\mathrm{Fe}$ 全金 系では測走温度範囲において酸素濃度は $100 \mathrm{ppm}$ 以下 であるため，第 3 項の影響は小さい。本研究のように 2 元系全域にわたる測走では $f_{\mathrm{Si}}^{\mathrm{Fe}}$ の影響を無視できない と考えられるが, 利用できる数值が報告されていないの で，次式のように表示する.

$\log f_{0}^{\mathrm{Fe}}+1 / 2 \log f_{\mathrm{Si}}^{\mathrm{Fe}}$

$$
\begin{aligned}
& =1 / 2\left(\log K_{\mathrm{SiNi} \mid}-\log K_{\mathrm{Si}(\mathrm{Ni}-\mathrm{Fe})}^{\prime}-0.06[\% \mathrm{Si}]\right. \\
& +0.11[\% \mathrm{O}])
\end{aligned}
$$

$\mathrm{Ni}-\mathrm{Fe}$ 系の珪素による脱酸の濃度積 $\log K_{\mathrm{SiNi}-\mathrm{Fe})}^{\prime}$ と 鉄濃度との関係を Fig. 5 に示す。 $\log K_{\mathrm{SiNi}-\mathrm{Fe})}^{\prime}$ は 20 


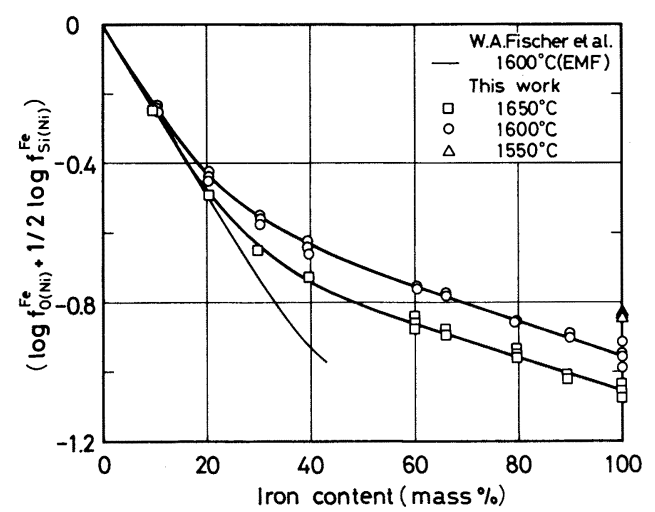

Fig. 6. Relation between $\left(\log f_{O(\mathrm{Ni})}^{\mathrm{Fe}}+1 / 2 \log f_{\mathrm{Si}(\mathrm{Ni})}^{\mathrm{Fe}}\right)$ and iron content in $\mathrm{Ni}-\mathrm{Fe}$ alloys.

Table 5. Interaction parameter.

\begin{tabular}{|c|c|c|}
\hline Author & $\begin{array}{l}e_{\mathrm{O}(\mathrm{Ni})}^{\mathrm{Fe}}+1 / 2 e_{\mathrm{Si}(\mathrm{Ni})}^{\mathrm{Fe}} \\
\text { or } e^{\mathrm{Fe}}(\mathrm{Ni})\end{array}$ & Remarks \\
\hline $\begin{array}{l}\text { SAKAO \& SANO } \\
\text { FISCHER et al. } \\
\text { This work }\end{array}$ & $\begin{array}{l}-0.026 \\
-0.025 \\
-0.025\end{array}$ & $\begin{array}{lll}1600^{\circ} \mathrm{C} & \mathrm{Fe}<25 \% & \mathrm{H}_{2}-\mathrm{H}_{2} \mathrm{O} \\
1600^{\circ} \mathrm{C} & \mathrm{Fe}<25 \% & \mathrm{EMF} \\
1600^{\circ} \mathrm{C}-1650^{\circ} \mathrm{C} & \mathrm{Fe}<10 \%\end{array}$ \\
\hline
\end{tabular}

mass\% まで急激に上昇し，その後ゆるやかになり，40 mass\% Fe から純鉄まで值線的に推移している。 Ni 側 における $\log K_{\mathrm{SiNi}-\mathrm{Fe} /}^{\prime}$ の実験式は次の(14)式で表され る.

$\log K_{\mathrm{Si}(\mathrm{Ni}-\mathrm{Fe})}^{\prime}=\log K_{\mathrm{Si}(\mathrm{Ni})}-(288 / T-0.197)[\% \mathrm{Fe}]$

$\mathrm{Fe}<20$ mass \%, 0.5 mass \% Si,

$1600^{\circ} \mathrm{C} \sim 1650^{\circ} \mathrm{C}$

Fig. 6 は (12)式より得られた $\left(\log f_{0}^{\mathrm{Fe}}+1 / 2 \log f_{\mathbf{S i}}^{\mathrm{Fe}}\right)$ と鉄濃度との関係である. 脳中, FISCHER ら ${ }^{22)}$ の值は本 研究の $1650^{\circ} \mathrm{C}$ の結果と 20 mass\% Fe まで一致してお り,これらの值 ${ }^{16) 22)}$ を Table 5 に示す.

\section{$3 \cdot 2 \cdot 2$ 鉄基合金としての脱酸平衡}

溶鉄の珪素脱酸は鉄鋼製鍊の基礎的な反心系であり, 従来多数の報告があるが, 本研究の結果を検証する意味 を含めて, Fig. 5 に示したように純鉄についても測定し, 併せて $\mathrm{Fe}-\mathrm{Ni}$ 系の実測の-..例として, 鈴木ら ${ }^{23)}$ の結果 を四示した。

純鉄の珪素による脱酸の濃度積 $\log K_{\mathrm{SiFe} \text { ) }}^{\prime}$ は, Fig. 7 に示すように的場ら ${ }^{24)}$ および鈴木ら ${ }^{23)}$ の $\log K_{\mathrm{Si}|\mathrm{Fe}|}$ お よび $\log K_{\mathrm{SiFe}}^{\prime}$ の值とよく一致している.すなわち, 鈴 木ら ${ }^{23)}$ の約 0.9 mass\% Si までの測定結果によれば, $\log K_{\mathrm{SiFe}}^{\prime}$ の珪素濃度依存性は認められておらず, $\log$ $K_{\mathrm{SiFe}}^{\prime}$ は $\log K_{\mathrm{SiFe}}$ に等しい. 汹中の本研究結果を示す 直線は (15) 式で示され, $1600^{\circ} \mathrm{C}$ では $\log K_{\mathrm{siFe},}=$ - 4.670 である.

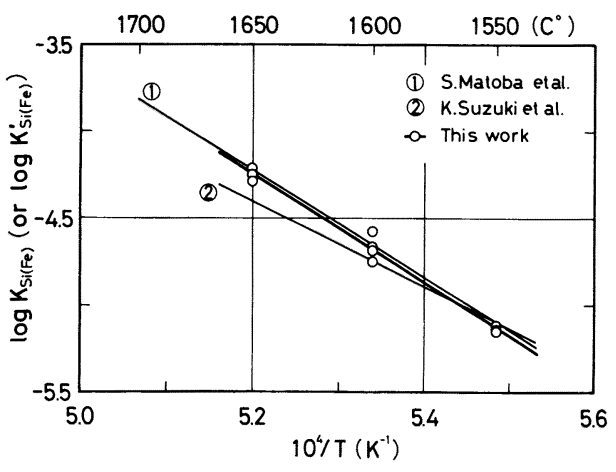

Fig. 7. Temperature dependence of $\log K_{\mathrm{Si}(\mathrm{Fe})}$.

$\log K_{\mathrm{Si}(\mathrm{Fe})}=-30960 / T+11.86$

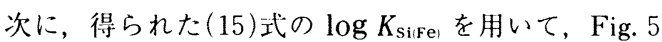
の鉄側における $\log K_{\mathrm{Si} \text { Fe }-\mathrm{Ni})}^{\prime}$ と $\mathrm{Ni}$ 濃度との関係を実験 式として求めると(16)式で表される.

$\log K_{\mathrm{Si}(\mathrm{Fe}-\mathrm{Ni})}^{\prime}=\log K_{\mathrm{SiFe}}-0.01[\% \mathrm{Ni}]$

$\mathrm{Ni}<60$ mass $\%, \quad 0.5$ mass $\% \mathrm{Si}$,

$1600^{\circ} \mathrm{C} \sim 1650^{\circ} \mathrm{C}$

鉄合金系の平衡走数は (12)式と同様に脱酸の濃度積, 活量係数および濃度を用いて整理すると(17)式で示され る.

$$
\begin{aligned}
\log K_{\mathrm{Si}(\mathrm{Fe})} & =\log K_{\mathrm{Si}(\mathrm{Fe}-\mathrm{Ni})}^{\prime}+\log f_{\mathrm{Si}}+2 \log f_{0} \\
& =\log K_{\mathrm{Si}(\mathrm{Fe}-\mathrm{Ni})}^{\prime}+\log f_{\mathrm{Si}}^{\mathrm{Si}}+\log f_{\mathrm{Si}}^{0} \\
& +\log f_{\mathrm{Si}}^{\mathrm{Ni}}+2\left(\log f_{0}^{0}+\log f_{0}^{\mathrm{Si}}+\log f_{0}^{\mathrm{Ni}}\right) \\
& =\log K_{\mathrm{Si}(\mathrm{Fe}-\mathrm{Ni})}^{\prime}+\left(e_{\mathrm{Si}}^{\mathrm{Si}}+2 e_{0}^{\mathrm{Si}}\right)[\% \mathrm{Si}] \\
& +\left(e_{\mathrm{Si}}^{0}+2 e_{0}^{0}\right)[\% \mathrm{O}]+\left(e_{\mathrm{Si}}^{\mathrm{Ni}}+2 e_{0}^{\mathrm{Ni}}\right)[\% \mathrm{Ni}]
\end{aligned}
$$

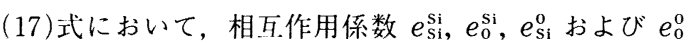
の值には純鉄の珪素脱酸に関する学:振の推奨平衡値 ${ }^{25)}$


あるが、ここでは $\mathrm{H}_{2} / \mathrm{H}_{2} \mathrm{O}$ で平衡測定した坂尾ら ${ }^{26)}$ の 值， $e_{0}^{\mathrm{Ni}}=0.005$ を採用する.これらの相互作用係数を 用いて本研究の結果を(17)式で整理すると， $e_{\mathrm{Si}}^{\mathrm{Ni}}$ の值が 予測される.

Fig. 8 は得られた $\log f_{\mathrm{Si}}^{\mathrm{Ni}}$ と $\mathrm{Ni}$ 濃度との関係を示し たものであり，図中の直線の勾配より $e_{\mathrm{Si}}^{\mathrm{Ni}}=0.001$ が 得られる. $e_{\mathrm{Si}}^{\mathrm{Ni}}$ の值に関して, CHIPMAN ${ }^{26)}$ は KöRBER $ら^{27) 28)}$ の平衡測定結果より $e_{\mathrm{Si}}^{\mathrm{Ni}}$ を検專し，低 $\mathrm{Ni}-\mathrm{Fe}$ 合 金, $1600^{\circ} \mathrm{C}$ において $\log f_{\mathrm{Si}}^{\mathrm{Ni}}=0.005[\% \mathrm{Ni}]$ を報告し ている.

\section{4. 結言}

溶融 $\mathrm{Ni}$ および $\mathrm{Ni}-\mathrm{Fe}$ 命金 2 元系金域にわたり, 珪 


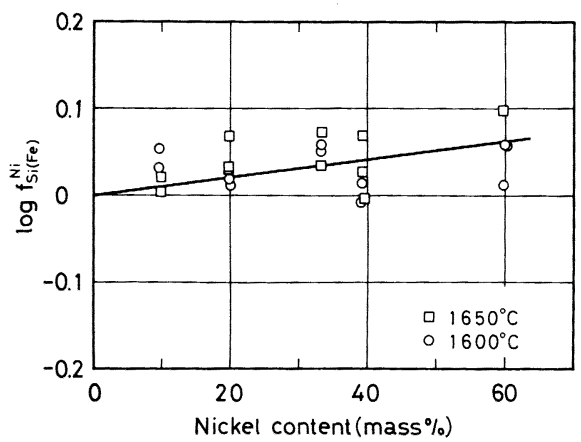

Fig. 8. Plot of $\log f_{\mathrm{Si}(\mathrm{Fe})}^{\mathrm{Ni}}$ vs. nickel content in $\mathrm{Fe}-\mathrm{Ni}$ alloys.

\section{素による脱酸平衡を測定して次の結果を得た。}

1 ) 溶融 $\mathrm{Ni}$ の珪素による脱酸の平衡定数抢よび濃度 積は $1500^{\circ} \mathrm{C} \sim 1650^{\circ} \mathrm{C}$ の範用で次の式で示される.

$\log K_{\mathrm{SiNi}}=-15680 / T+1.83$

$\log K_{\text {SiNi }}^{\prime}=\log K_{\text {SiNi }}-0.06[\% \mathrm{Si}] \quad \mathrm{Si}<2 \mathrm{mass} \%$

2) $\mathrm{Ni}-\mathrm{Fe}$ 合金系の $\mathrm{Ni}$ 側に扩ける脱酸の濃度積の実 験式は $1600^{\circ} \mathrm{C} \sim 1650^{\circ} \mathrm{C}$ の範井に扔いて次式で表され， $\left(\log f_{\mathrm{O}}^{\mathrm{Fe}}+1 / 2 \log f_{\mathrm{Si}}^{\mathrm{Fe}}\right)=-0.025[\% \mathrm{Fe}]$ を得た。

$\log K_{\mathrm{SiNi}-\mathrm{Fel}}^{\prime}=\log K_{\mathrm{SiNi} i}-(288 / T-0.197)[\% \mathrm{Fe}]$

$\mathrm{Fe}<20$ mass \%, 0.5 mass $\% \mathrm{Si}$

3 ）溶鉄の脱酸平衡定数は $1550^{\circ} \mathrm{C} \sim 1650^{\circ} \mathrm{C}$ の範囲 で次式が得られた。

$\log K_{\text {Sife) }}=-30960 / T+11.86$

4) $\mathrm{Ni}-\mathrm{Fe}$ 命金系の鉄側における脱酸の濃度積の実 験式は $1600^{\circ} \mathrm{C} \sim 1650^{\circ} \mathrm{C}$ において次の式で示される.

$\log K_{\text {Sife-Ni) }}^{\prime}=\log K_{\text {Sife, }}-0.01[\% \mathrm{Ni}]$

$\mathrm{Ni}<60$ mass $\%, \quad 0.5$ mass $\% \mathrm{Si}$

また，溶鉄中の珪素の活量係数におよぼす $\mathrm{Ni}$ の影響 について検討した。

終わりにあたり, 本研究遂行に学部学生として御協力 いただいた芦澤芳夫修士（現：日本クレイ(株)) および 花田光生学士（現：日本治金工業(株)）に深く感謝いた します。また，珪素分析のために ICP 発光分光分析装 置を利用させていただいた宫城県工業技術センター, 吉田 徹課長に感謝いたします。

\section{文南}

1 ) C. $K$. KIm, $A$. MCLEAN, $F$. ISHII and $S$. Ban-ya: ISS Trans., 8 (1987), p. 29

2 ) 石井不二夫, 井目漛孝, 萬谷志郎: 鉄と鋼, 69 (1983), p. 913

3 ) F. IshiI, Y. IgUCHI and S. Ban-ya: Trans. Iron Steel Inst. Jpn., 26 (1986), p. 128

4) H. A. Wriedt and J. Chipman: J. Metal. Trans., 8 (1956), p. 1195

5 ) E. S. Tankins, $N$. A. Gokcen and G. R. Belton: Trans. Metall. Soc. AIME, 230 (1964), p. 820

6 ) J. E. BowERS: J. Inst. Met., 90 (1961/62), p. 321

7 ) K. T. JACOB: Metall. Trans. B, 17 (1986), p. 763

8 ) W. Oflsen and G. Kremer: Mitt. Kaiser-Wilhelm-Inst. Eisenforsch., Düsseldorf, 18 (1936), p. 90

$9) Y u . V$. Tarakanov, $P . A$. Cherkasov, $V . V$. Averin and $A$. M. SAmarin: Dokl. Akad. Nauk, SSSR, 163 (1965), p. 166

10) G. Scharf, $V . V$. Averin, $A$. Y. Polyakov and $A . M$. SAmarin: Izv. Vysshikh Uchebn. Zavedenii, Chernaya Met. (1958) 11, p. 29

11) $K$. SchWERdTFEger and H. J. Engell: Trans. Metall. Soc. AIME, 233 (1965), p. 1327

12）藤原達雄, 杉浦三郎: 鉄と䤱, 63 (1977), p. 2236

13) G. $K$. Sigworth, J. F. Elliott, G. Vaughn and $G . H$. GEIGER: Met. Soc. CIM, Annual volume (1977), p. 104

14) O. KubascheWSKI and E. LL. Evans: Metallurgical Thermochemistry (1958) [Pergamon Press]

15) $V . V$. Averin, $A . Y u$. Polyakov and $A . M$. Samarin: Izv. Akad. Nauk SSSR, Otd. Tekh., 8 (1957), p. 120

16）坂尾 弘, 佐野幸吉: 日本金属学会誌, 26 (1962), p. 30

17) W. A. Fischer and W. ACKERManN: Arch. Eisenhüttenwes., 37 (1966), p. 779

18) B. F. Belov, I. A. NovchatskiJ and $J u$. A. Lobanov: Izv. Akad. Nauk SSSR, Metally. (1967) 3, p. 53

19) D. JANKE and W. A. Fischer: Arch. Eisenhüttenwes., 46 (1975), p. 297

20）家守伸正, 片山巌, 幸塚善作: 日本金属学会誌, 40 (1976), p. 751

21) M. IwaSe, S. Miki and T. MoRi: J. Chem. Thermodynamics, 11 (1979), p. 307

22) W. A. Fischer, D. Janke and W. Ackermann: Arch. Eisenhüttenwes., 41 (1970), p. 361

23）鈴木 鼎, 萬谷志郎, 不破 補: 鉄と鋼, 56 (1970), p. 20

24）的場幸雄, 郡司好喜, 桑名 武: 鉄と鐝, 45 (1959), p. 1328

25) 製鋼反応の推奖平衡值改菏版 (日本学術振興会製鋼第 19 委員会編) (昭和 59 年 11 月)

26) J. Chipman: JISI, 180 (1955), p. 97

27) F. KörBER: Stahl Eisen, 57 (1937), p. 1349

28) F. KöRBER and W. OELSEN: Mitt. K. W. Inst. Eisenforsch., 18 (1936), p. 109 